\title{
Evaluation of Conservation Effects Assessment Project Grazing Lands conservation practices on the Cienega Creek watershed in southeast Arizona with AGWA/RHEM modeling tools
}

D.C. Goodrich, H. Wei, I.S. Burns, D.P. Guertin, K. Spaeth, M. Hernandez, C. Holifield-Collins, M. Kautz, P. Heilman, L.R. Levick, G. Ponce, E. Carrillo, and R. Tiller

\begin{abstract}
The Automated Geospatial Watershed Assessment Tool (AGWA) and the Rangeland Hydrology Erosion Model (RHEM) were used to evaluate conservation practices on the Cienega Creek watershed $(\mathrm{CCW})$ that were implemented under the Conservation Effects Assessment Project (CEAP) on Grazing Lands. CEAP on Grazing Lands is a multi-agency effort to quantify the environmental effects of conservation practices and programs, and develop the science base for managing rangelands for environmental quality using conservation practices (Spaeth et al.2013). The evaluation was performed on the CCW and the Empire Ranch, located in southeastern Arizona, where numerous conservation practices have been implemented to achieve their management goals of maintaining desired plant communities and watershed processes. To assess the effects of the conservation practices on long-term soil and water loss, RHEM was applied to the entire CCW using National Resources Inventory (NRI) data. Four analysis periods were selected based on climatic contrasts, conservation spending, and availability of NRI sample points. The CCW results showed that the simulations using RHEM parameters derived from NRI data could be used to demonstrate the impact of climate on vegetation condition and sediment yield. A subsection, dubbed "select treatment areas," of the CCW, which received extensive treatments with brush removal, prescribed burns, and stock ponds, was assessed using remotely sensed data. The select treatment areas were modeled over three different periods, representing preconservation spending, postconservation spending, and later postconservation spending. Remote sensing was capable of detecting and estimating the changes in vegetation cover from brush removal and prescribed burns. Simulations of sediment yield using pre- and posttreatment data indicated a modest reduction in sediment yield. Simulations in the select treatment areas indicated mechanical brush treatments were typically more effective than prescribed burns for improving watershed condition as estimated by reductions in sediment yield, but were more costly to implement. Stock ponds had a larger impact on sediment yield than the land treatments. The assessment demonstrated the utility of remotely sensed estimates of plant growth form and cover for model inputs to estimate changes in runoff and sediment yield with changing cover conditions over large areas.
\end{abstract}

Key words: assessment — erosion—rangelands—runoff—-sediment yield—watershed modeling

The Automated Geospatial Watershed Assessment (AGWA) Tool, the Rangeland Hydrology and Erosion Model (RHEM), National Resources Inventory (NRI) data, and remotely sensed data were used to address the Conservation Effects
Assessment Project (CEAP) on Grazing Lands (GL) goal of assessing the effects of rangeland conservation practices on soil and water. CEAP-GL is a multi-agency effort to quantify the environmental effects of conservation practices and programs and develop the science base for managing rangelands for environmental quality using conservation practices (Spaeth et al. 2013). For this case study, evaluations were performed on the Cienega Creek watershed (CCW) and the Empire Ranch, located in southeastern Arizona, where numerous conservation practices have been implemented by the Bureau of Land Management (BLM) to achieve their management goals of maintaining desired plant communities, water quality, and watershed processes (figure 1). To assess the effects of the conservation practices on long-term soil and water loss, RHEM was applied to the entire CCW using NRI data for a large-scale assessment. The analysis periods were selected based on climatic contrasts, conservation spending, and availability of NRI sample points. A subsection of the Empire Ranch, dubbed "select treatment areas," and a specific 61.7 ha watershed were assessed using remotely sensed data for a small-scale assessment. The select treatment areas were treated with brush removal, prescribed burns, and a stock pond, and were modeled over three different periods, representing preconservation spending, postconservation spending, and later postconservation spending.

In this case study, vegetation and ground cover characteristics (plant basal cover, litter, rock, and biological soil crusts) were determined for time periods with different climate conditions and levels of conservation practice implementation. NRI data provide a large-scale, regional evaluation of vege-

David C. Goodrich is a research hydraulic engineer, USDA Agricultural Research Service (ARS) Southwest Watershed Research Center, Tucson, Arizona. Haiyan Wei is an assistant research scientist, I. Shea Burns is a senior research specialist, and D. Phillip Guertin is a professor, all at University of Arizona, Tucson, Arizona. Ken Spaeth is a rangeland management specialist, USDA Natural Resources Conservation Service (NRCS), Fort Worth, Texas. Mariano Hernandez is a hydrologist, Chandra Holifield-Collins is a plant physiologist, Mark Kautz is a hydrologist, and Philip Heilman is a research biologist, all at the USDA ARS Southwest Watershed Research Center, Tucson, Arizona. Lainie R. Levick is a principal research specialist, University of Arizona, Tucson, Arizona. Guillermo Ponce is an assistant research scientist, USDA ARS Southwest Watershed Research Center, Tucson, Arizona. Emilio Carrillo is a rangeland management specialist, USDA NRCS, Tucson, Arizona. Ron Tiller is a research associate, Desert Botanical Garden, Phoenix, Arizona. 
Figure 1

Location maps of the Cienega Creek watershed (CCW), the Empire Ranch, and treatment locations in southeastern Arizona and Major Land Resource Area (MLRA) 41.

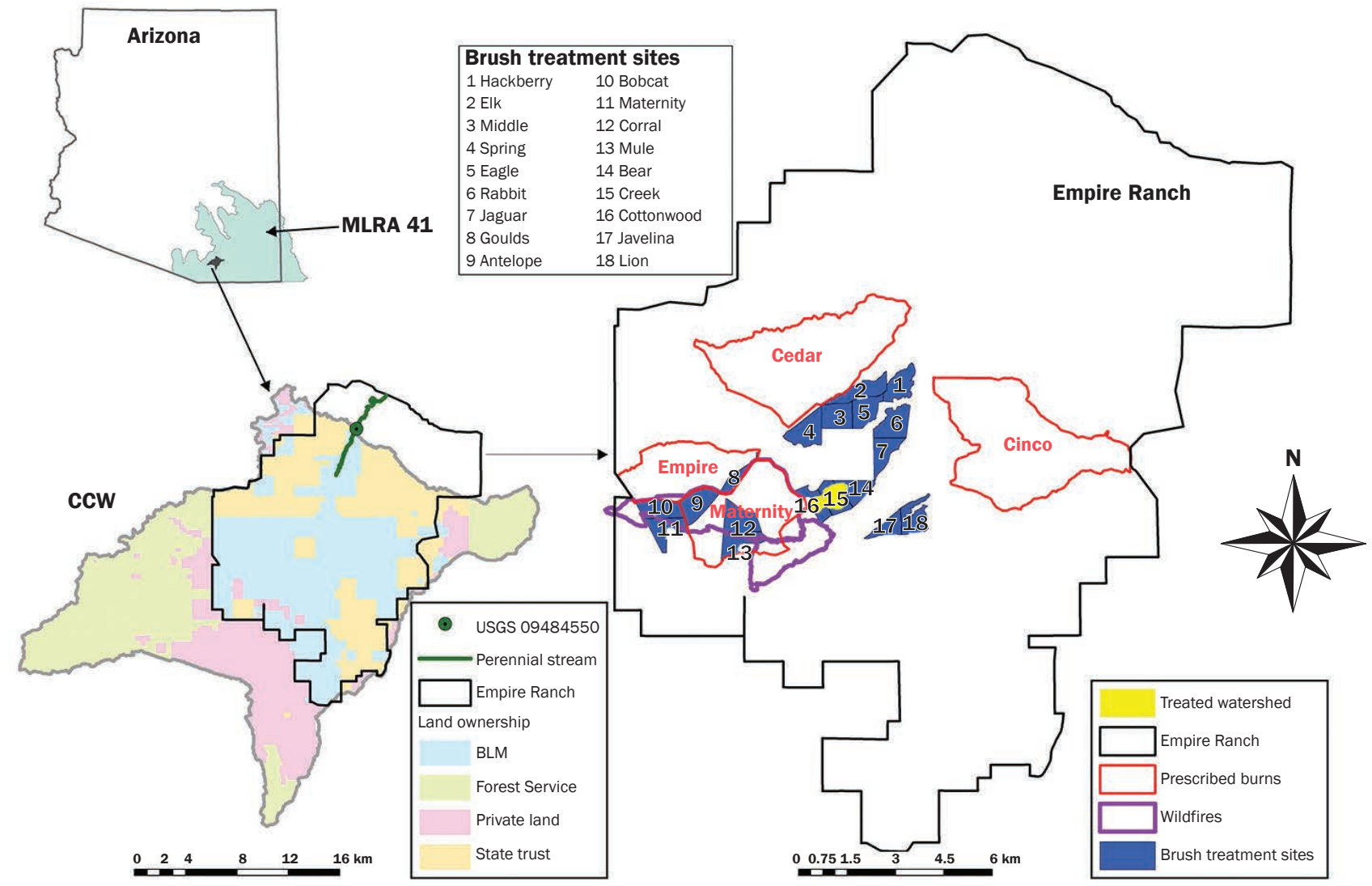

tation condition, whereas remotely sensed data can provide a small-scale, site-specific representation of vegetation condition. The advantages and disadvantages of the two methods for evaluating conservation practices will be presented.

Study Site Description. The CCW is located in southeastern Arizona (figure 1) in Major Land Resource Area 41 (MLRA 41). The entire watershed has a drainage area of $1,570 \mathrm{~km}^{2}$, but this analysis will focus on the $513 \mathrm{~km}^{2}$ of the watershed upstream of US Geological Survey (USGS) stream gauge 09484550. The CCW lies in the Basin and Range physiographic province that is characterized by a series of mid- to high-elevation mountain ranges separated by broad low-elevation basins. Vegetation communities include plains, great basin and semidesert grasslands, Chihuahuan desert scrub, Madrean evergreen woodlands, and a small portion of Rocky Mountain and montane conifer forest. Based on the National Hydrography Dataset (NHD; https://www. usgs.gov/core-science-systems/ngp/nation- al-hydrography), about $2.7 \%$ of the streams in the CCW are classified as perennial; limited reaches of riparian vegetation occur adjacent to these perennial reaches, consisting of mixed broadleaf trees, mesquite, and relatively dense understory. The watershed has no major reservoirs or impoundments, but does have more than 100 stock ponds to provide water for cattle and wildlife (Renwick et al. 2005). Primary land uses include grazing, recreation, fuelwood cutting, and domestic ranching and farming. Precipitation data from 1895 to 2016 derived from the $800 \mathrm{~m}$ PRISM data (Parameterelevation Regressions on Independent Slopes Model, http://www.prism.oregonstate. edu/) show an average of $448 \mathrm{~mm}$ over the watershed (sd $=107 ; \mathrm{CV}=0.24)$, with a low of $224 \mathrm{~mm}$ in 1953, and a high of $872 \mathrm{~mm}$ in 1905. Figure 2 shows the long-term precipitation, temperature, the annual Standardized Precipitation-Evapotranspiration Index (SPEI; Vicente-Serrano et al. 2010) in MLRA 41 derived from $800 \mathrm{~m}$ PRISM data, the number of cattle in Arizona, and conser- vation spending in the $\mathrm{CCW}$ (the long-term grazing and conservation spending data in MLRA 41 are not available). Part of this assessment will focus on the Empire Ranch, located in the CCW (figure 1), where numerous conservation practices have been implemented. Prescribed seasonal grazing on the Empire Ranch is managed with a goal of maintaining less than 30\% exposed soil and $10 \%$ or greater basal cover of desired perennial grasses (Gori and Schussman 2005). The Empire Ranch is a high profile multiple-use area that includes BLM, Pima County, State Trust, and private lands. It is managed cooperatively with significant citizen input, is actively used for cattle ranching, and has had yearly vegetation monitoring conducted since 2004

Conservation Practices in the Study Watershed. Primary conservation and management practices that have been implemented in the study watershed are prescribed grazing (including practices to control the amount and timing of grazing, such as fencing and watering points) and prescribed fire 


\section{Figure 2}

Graphs of (a) cattle numbers in Arizona and long-term conservation spending in the Cienega Creek watershed (CCW), and (b) precipitation, (c) temperature, and (d) Standardized Precipitation-Evapotranspiration Index (SPEI) from 1895 to 2016 in Major Land Resource Area (MLRA) 41. Conservation investment figures combine the USDA Natural Resources Conservation Service (NRCS)-Environmental Quality Incentives (EQIP) and Bureau of Land Management (BLM) brush management expenditures. Filled symbols for temperature are in the $80^{\text {th }}$ percentile or above; for SPEl they are in the lowest $20 \%$.

(a)

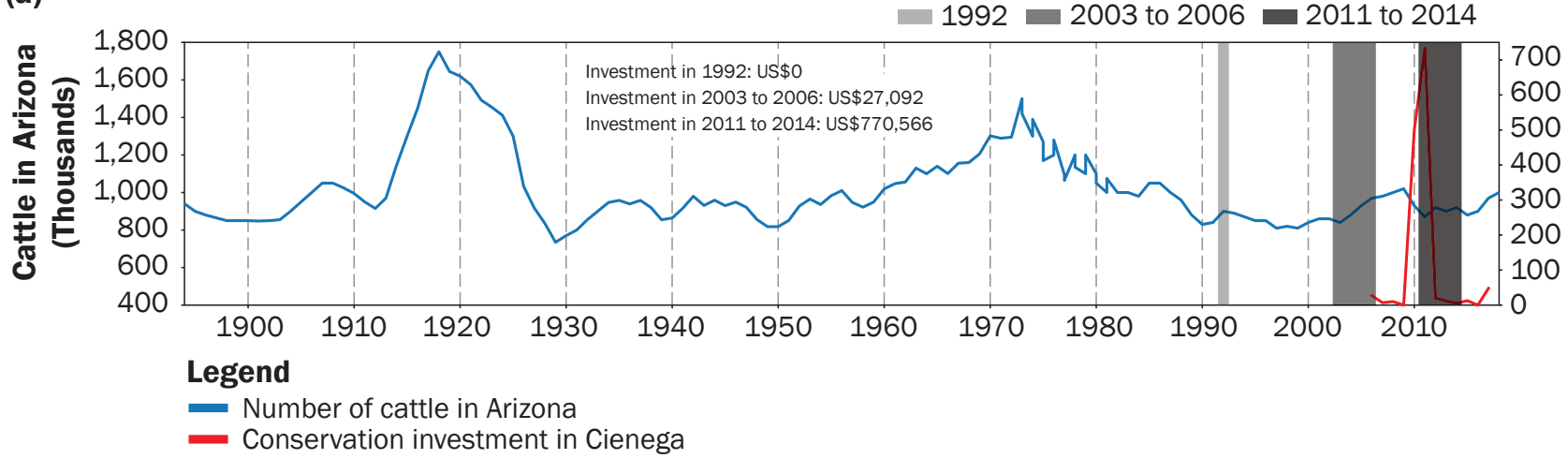

(b)

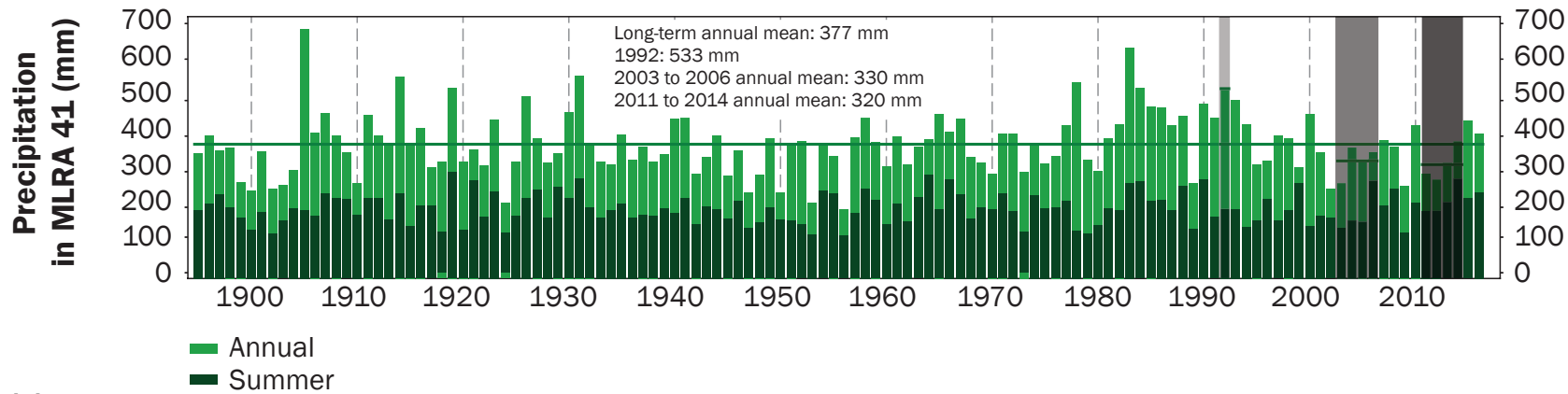

(c)

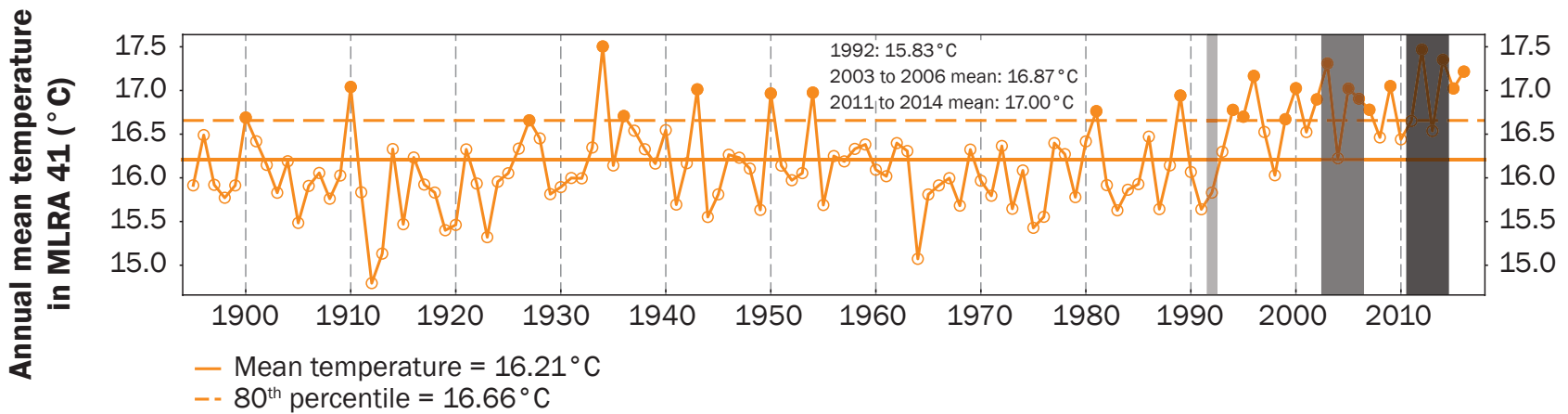

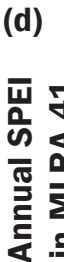

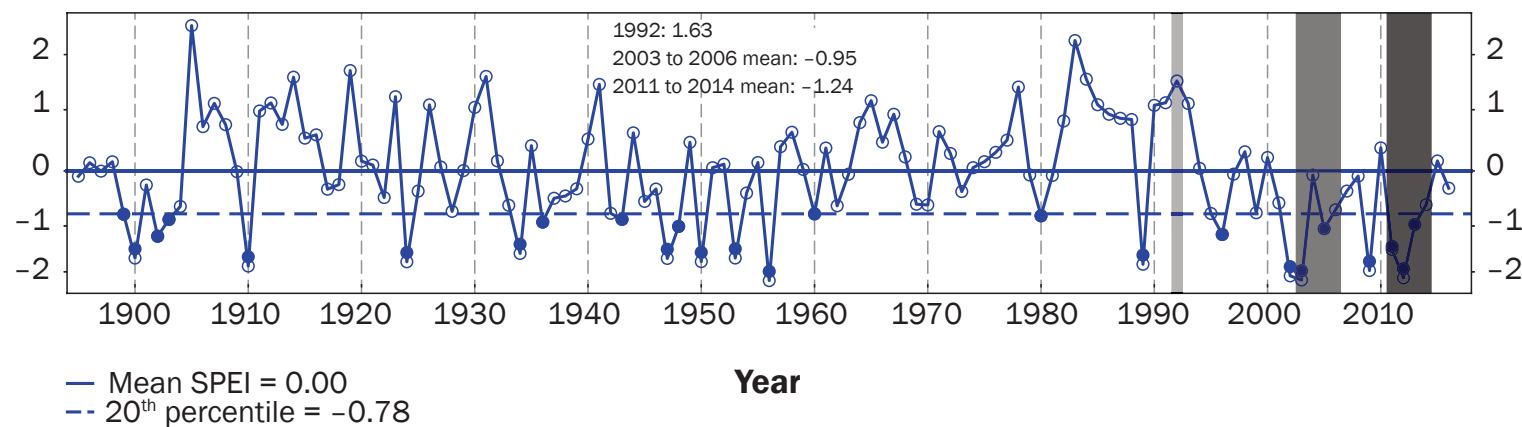


and brush management (removal) to increase forage and reduce losses of soil and nutrients. Prior to and including the early 1990s, conservation practices recorded in the USDA Natural Resources Conservation Service (NRCS) database show a point location of where a practice was implemented, but not the areal extent over which it was applied. Historical records of cattle numbers, where they grazed, and for what duration, are not available from the NRCS. Starting in 1995, detailed grazing, conservation and management practices, and spending data are available for the Empire Ranch.
The NRCS has invested US $\$ 2.3$ million in conservation practices on the Empire Ranch from 2007 to 2016 through the NRCS Environmental Quality Incentives Program (EQIP) (https://www.nrcs.usda. gov/wps/portal/nrcs/main/national/programs/financial/eqip/), including prescribed fire and brush removal treatments. In 2010 and 2011, BLM invested over US\$1.4 million on mechanical brush grubbing on over $12 \mathrm{~km}^{2}$ (Tiller et al. 2012; figure 1 and table 1). Investing in conservation practices in southern Arizona began in 1996, and in the CCW in 2006, with primary spending on prescribed grazing, pumping plants, and brush management.

Monitored Watershed Condition and Factors in Rangeland Assessment. Watershed condition is primarily assessed by the NRCS as part of the NRI (Herrick et al. 2010) by monitoring vegetation type, canopy cover, ground cover, and soil properties. These data are used to estimate the susceptibility of hillslope areas to erosion, and therefore their long-term sustainability. The vegetation transect data collected for the NRI program provide nationally

\section{Table 1}

Bureau of Land Management (BLM) spending on conservation treatments at Empire Ranch from 2007 to 2011. See figure 1 for locations.

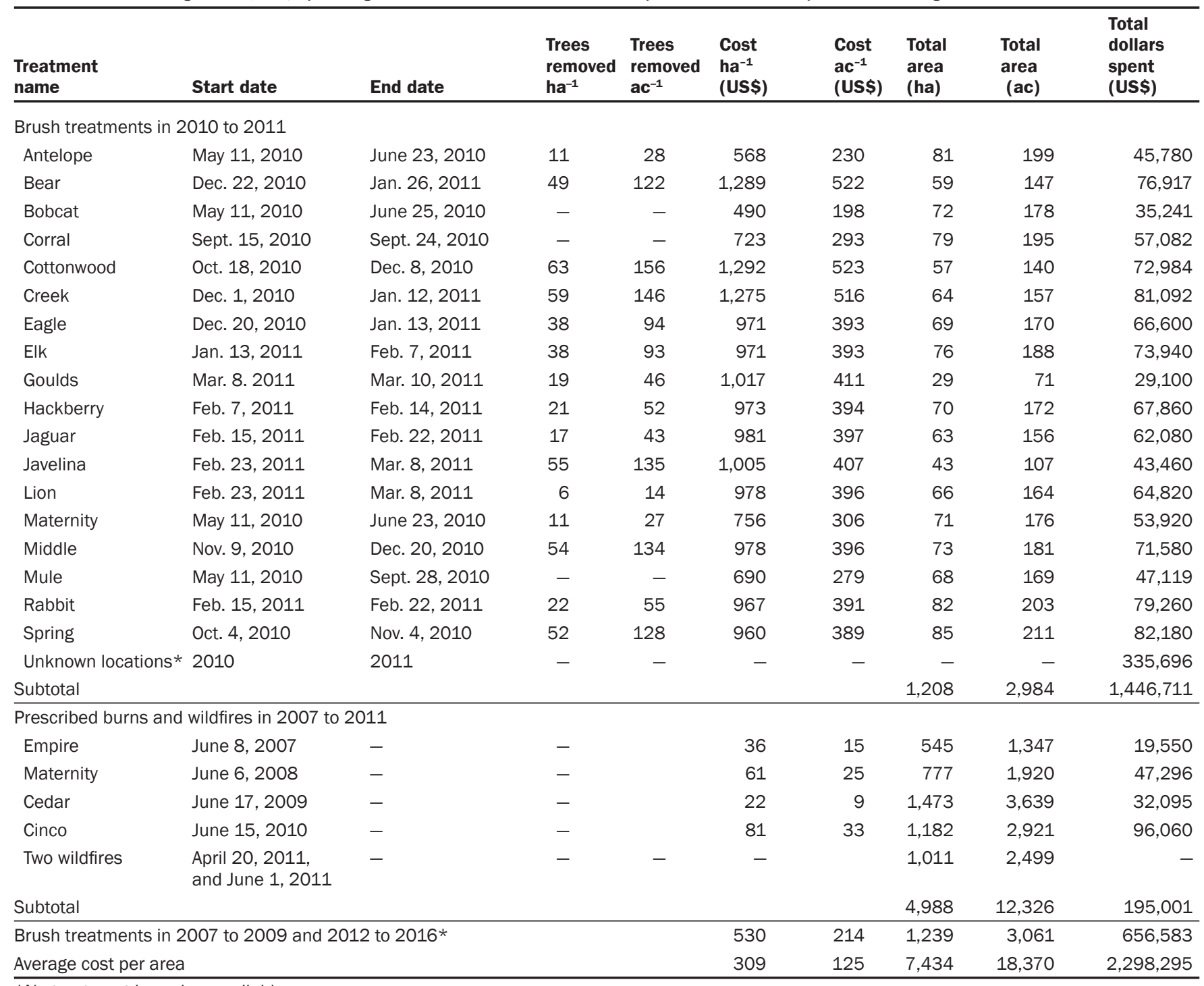

*No treatment boundary available. 
consistent ground-sampled data on the status, condition, and trends of land, soil, water, and related resources on an ecological site (ES) basis (Herrick et al. 2002; Pellant 2018; Spaeth et al. 2005). An ES is a conceptual division of the landscape based on unique physical attributes (climate, soils, landscape position, and topography) that govern the ability to produce characteristic vegetation and to respond to management and disturbances (Williams et al. 2016). Reducing erosion and sediment yield is one of the primary goals of conservation practices in rangeland systems; however, direct measurements of erosion and sediment yield are generally conducted only in research situations. Consequently, during the conservation planning phase and on an ES basis, land management agencies (i.e., USDA NRCS and US Department of the Interior Bureau of Land Management) conduct rangeland health assessments to ascertain biotic integrity of the vegetative community and its condition, its hydrologic function, and soil and surface stability (Herrick et al. 2002; Pellant 2018; Spaeth et al. 2005) through its NRI data collection program. The NRI rangeland program samples conditions at the national level, and at scales associated with MLRAs and Ecoregions (levels III and IV) (Spaeth et al. 2003). In addition, the NRI rangeland program calculates a similarity index (SI) at each NRI sample location. The SI determines the percentage similarity ( $0 \%$ to $100 \%$ ) of the surveyed vegetation in relation to the Reference Plant Community (RPC) documented in the respective ES descriptions (ESDs) (MuellerDombois and Ellenberg 1974; USDA NRCS 2018a). The RPC represents the expected norm, reference point, or state in the ESD "State and Transition" model (S\&TM) for an ES, where plant community composition and natural disturbance regimes trace back to pre-European settlement (500 years or less), based on the least disturbed sites still extant.

Assessments for rangeland condition reflect "key issues in rangeland science, including rangeland health, nonnative plant species, native and nonnative invasive plant species, bare ground, intercanopy gaps, and soil surface aggregate stability" (USDA NRCS 2018b). The condition of a rangeland is qualitatively assessed by comparing these attributes and indicators of its current functional state relative to the RPC. The RPC as determined from the ESD will be used as the baseline in the relative change analysis. In this case study, vegetation condition will be described for ESs in the MLRA 41 in southeastern Arizona (figure 1) using NRI data.

Erosion Modeling. The AGWA tool and RHEM were used to estimate hillslope erosion. RHEM has been validated using high-quality observations from the nearby USDA Agricultural Research Service (ARS) Walnut Gulch Experimental Watershed and from rainfall-simulator experiments across the western United States (Hernandez et al. 2017). RHEM was developed in the early 2000 s as a tool to assess runoff and erosion rates on western rangelands for purposes of conservation planning and regional resource assessments. RHEM was specifically designed so its hydrology and erosion parameters can be estimated from field data collected nationally as part of the ongoing NRI program (Herrick et al. 2010), as well as from nationally available soils data. Rangeland managers can therefore apply RHEM using the NRI database without additional field data collection. However, site-specific data collected on a range or allotment is preferable if time and resources allow. RHEM input data requirements include plant growth form (bunchgrasses, sod grasses, shrubs, and forbs/annual grasses) and surface ground cover (rock, litter, basal cover, and biological soil crusts). The RHEM model is described in detail in Hernandez et al. (2017) and Al-Hamdan et al. (2017). Additional information can be found at the RHEM website (https://apps.tucson.ars.ag.gov/rhem/). Table 2 summarizes the hydrology and erosion parameters in RHEM and their independent soil, vegetation, and slope variables.

AGWA (Miller et al. 2007; https://www. tucson.ars.ag.gov/agwa) is a geographic information systems (GIS) interface that uses nationally available geospatial data layers to automate the time-consuming tasks of watershed delineation into distributed model elements, model parameterization

\section{Table 2}

Rangeland Hydrology and Erosion Model (RHEM) hydrology and erosion parameters and their independent variables.

\begin{tabular}{lll}
\hline Parameters & Description & Independent variables \\
\hline $\mathrm{Ke}$ & Effective saturated hydraulic conductivity & Litter and basal, and soil texture \\
$\mathrm{ft}$ & Hydraulic roughness coefficient & $\begin{array}{l}\text { Litter, rock, basal, biological soil } \\
\text { crust, and slope } \\
\text { Ground cover, foliar cover, }\end{array}$ \\
$\mathrm{K} s \mathrm{~s}$ & Splash and sheet erodibility factor & $\begin{array}{l}\text { Goul slope } \\
\text { and }\end{array}$ \\
$\mathrm{K} \omega$ & Concentrated flow erodibility coefficients & Litter, rock, clay, and silt \\
& for hillslope micro-channels &
\end{tabular}

of those elements, and execution of a suite of hydrologic and erosion models (RHEM, KINEROS2 [Goodrich et al. 2012] and SWAT [Arnold et al. 1998]). AGWA can difference results from multiple simulations to examine relative change over a variety of input scenarios (e.g., pre- and postimplementation of best management practices and conservation practices, land cover change, or present conditions versus alternative futures). This gives range conservationists and land managers the ability to easily identify potential problem areas where field inspections can be undertaken or where conservation practices can be focused.

\section{Materials and Methods}

AGWA/RHEM was applied in two assessments in this case study: a large- and a small-scale assessment. For the large-scale assessment, simulations were run for the entire CCW using RHEM parameters derived from NRI points collected in MLRA 41 (figure 1). For the small-scale assessment, the effects of brush removal treatments and a stock pond were evaluated for a specific 61.7 ha watershed located on the Empire Ranch (figure 1), and the effects of brush removal treatments and prescribed fire were evaluated for select treatment areas. The Cottonwood Creek and Bear treatment areas within the 61.7 ha watershed were treated in the winter of 2010 to 2011 , with US\$148,901 spent on mechanical shrub and mesquite removal (table 1). The total cost of brush treatments and prescribed fire applied to the select treatment areas was US $\$ 2,298,295$. Landsat satellite imagery was used to estimate vegetation cover change in the treated areas. Simulation results from pretreatment and posttreatment time periods were differenced to examine relative change. Landsat satellite imagery is used because it can capture local 
land cover changes from conservation efforts such as brush management that isolated NRI sampling will not capture.

AGWA Simulations. For the large-scale assessment, the $513 \mathrm{~km}^{2} \mathrm{CCW}$ was discretized into 3,587 hillslope elements and 1,457 channel elements using a 1,000 $\mathrm{m}$ flow length threshold, which effectively defines the stream network as where flow paths exceed $1,000 \mathrm{~m}$ and maximum hillslope flow length is limited to $1,000 \mathrm{~m}$. For the small-scale assessment of the 61.7 ha treated watershed, 33 hillslope elements and 13 channel elements were discretized using a $500 \mathrm{~m}$ flow length threshold. For the small-scale assessment of the select treatment areas, a subset of the hillslopes from the large-scale assessment were used. The National Elevation Dataset (NED; http://ned.usgs.gov/) was used for the digital elevation model to perform the delineation and discretization of the CCW. The NED data were downloaded from the US Geological Survey (USGS) National Map Viewer and Download Platform (https://viewer.nationalmap.gov/basic/) at $1 / 3$ arc-second resolution $(\sim 10 \mathrm{~m})$ for the entire CCW, and at $1 \mathrm{~m}$ resolution for the 61.7 ha treated watershed.

The 61.7 ha watershed simulations across different periods were performed with and without a stock pond. This allowed comparison of the relative effects on runoff and sediment yield resulting from cover and vegetation change across the time periods to a more direct conservation practice (e.g., stock ponds). An existing stock pond at the Empire Ranch draining an area similar to the two selected watersheds was characterized using airborne Light Detection and Ranging (LiDAR) to develop stage versus volume and surface area estimates. The stock pond had dead storage of $2,887 \mathrm{~m}^{3}$ at the height of the bottom of the spillway $(1.56 \mathrm{~m})$. The spillway stage-discharge relationship was approximated with a broad-crested weir equation with dimensions estimated from LiDAR and aerial imagery. The stock pond is represented as a separate model element. Once the relationships discussed above are developed, the pond element can be placed downstream of the outlet channel element of the 61.7 ha watershed. This allows the evaluation of a stock pond conservation (and water source) practice on sediment retention.

In conducting the model simulations for this study we used a relative change analysis because runoff and sediment observations needed to calibrate and validate the model were not available for the watershed. The assumption is that model uncertainty is the same for all cases, and the relative change between cases captures the response differences; therefore, relative change can be used to assess risk or evaluate treatment effectiveness (Harmel et al. 2014; Sidman et al. 2016). Relative change generated from two conservation periods with the same rainfall reflects the impact of land cover change occurring between the two periods. For sediment yield, the following equation was used to compute relative change in percentage:

$$
\begin{aligned}
& \text { Relative Change }=\left(\text { Sediment }_{\text {period } 2}-\text { Sediment }_{\text {period } 1}\right) \\
& \div \text { Sediment }_{\text {period } 1} \times 100 \% .
\end{aligned}
$$

In equation 1 , if less erosion occurs in the second period, the relative change will be negative. This indicates an improvement in watershed condition from period one to period two as less erosion and sediment yield were produced under the same storm conditions in the later period, assuming improved vegetation cover conditions, and only applies to erosion and sediment yield. A 10-year one-hour National Oceanic and Atmospheric Administration (NOAA) design storm (53.37 $\mathrm{mm}$ average across the watershed) was used for both the large-scale and small-scale assessments.

Large-Scale Assessment. Besides the RPC condition, three time periods representing different climatic conditions and levels of conservation activities were defined (table 3 ):

1. the "1992" or "preconservation" period, when the earliest years NRI records were available, representing a period of wet climatic conditions (annual precipitation is
$533 \mathrm{~mm}$ ) prior to any significant conservation spending;

2. the "2003 to 2006 " period representing a dry and warm period (mean annual precipitation of $330 \mathrm{~mm}$ ), with 7 to 11 years of EQIP conservation investments in MLRA 41, and just prior to initiation of conservation spending in the CCW; and

3. the "2011 to 2014 " period representing a deepening drought (mean annual precipitation of $320 \mathrm{~mm}$ ) with the latest sampling of NRI and 15 to 19 years of EQIP spending in MLRA 41, and 5 to 10 years of spending in the CCW.

Applying NRI point data to large areas requires extrapolation and up-scaling of point data. A map developed by the NRCS showing the $27 \mathrm{ESs}$ in the CCW was initially considered for extrapolating the ES-based NRI data to the entire watershed. However, only one NRI sample point is actually located within the CCW, and even for the whole MLRA 41 not all of the 27 ESs had a sufficient number of NRI points for the different periods of analysis. Therefore, the $27 \mathrm{ESs}$ in the CCW were grouped using hierarchical clustering into 7 ES associations based on similar annual precipitation (timing and amount), species composition, vegetative productivity, soil texture, and slope (figure 3 and table 4). Areas with a combination of two ESs are categorized as "mixed" but were still represented proportionally. Flexible beta linkage clustering was used to identify and construct the ES associations based on plant community composition (McCune and Grace 2002; PC-ORD v 7.0). Nonmetric multidimensional scaling (NMDS) was used to ordinate ES plant species composition to examine patterns and dissimilarity among

\section{Table 3}

Four conservation periods used in the large-scale assessment.

\begin{tabular}{lll}
\hline Period of analysis & $\begin{array}{l}\text { Annual precipitation } \\
(\mathbf{m m})\end{array}$ & Conservation spending \\
\hline RPC & - & - \\
1992 (preconservation) & 533 & $\begin{array}{l}\text { Prior to any significant conservation } \\
\text { spending }\end{array}$ \\
2003 to 2006 & 330 & $\begin{array}{l}\text { With 7 to 11 years of EQIP investment } \\
\text { in MLRA-41 } \\
\text { With 15 to 19 years of EQIP investment } \\
\text { in MLRA-41 }\end{array}$ \\
\hline
\end{tabular}

Notes: RPC = Reference Plant Community. EQIP = Environmental Quality Incentives Program MLRA = Major Land Resource Area. 


\section{Figure 3}

Map showing the seven ecological site associations in the Cienega Creek watershed (CCW) created by grouping the 27 ecological sites. The black outline represents the Empire Ranch. Areas with combined ecological sites are categorized as "Mixed."

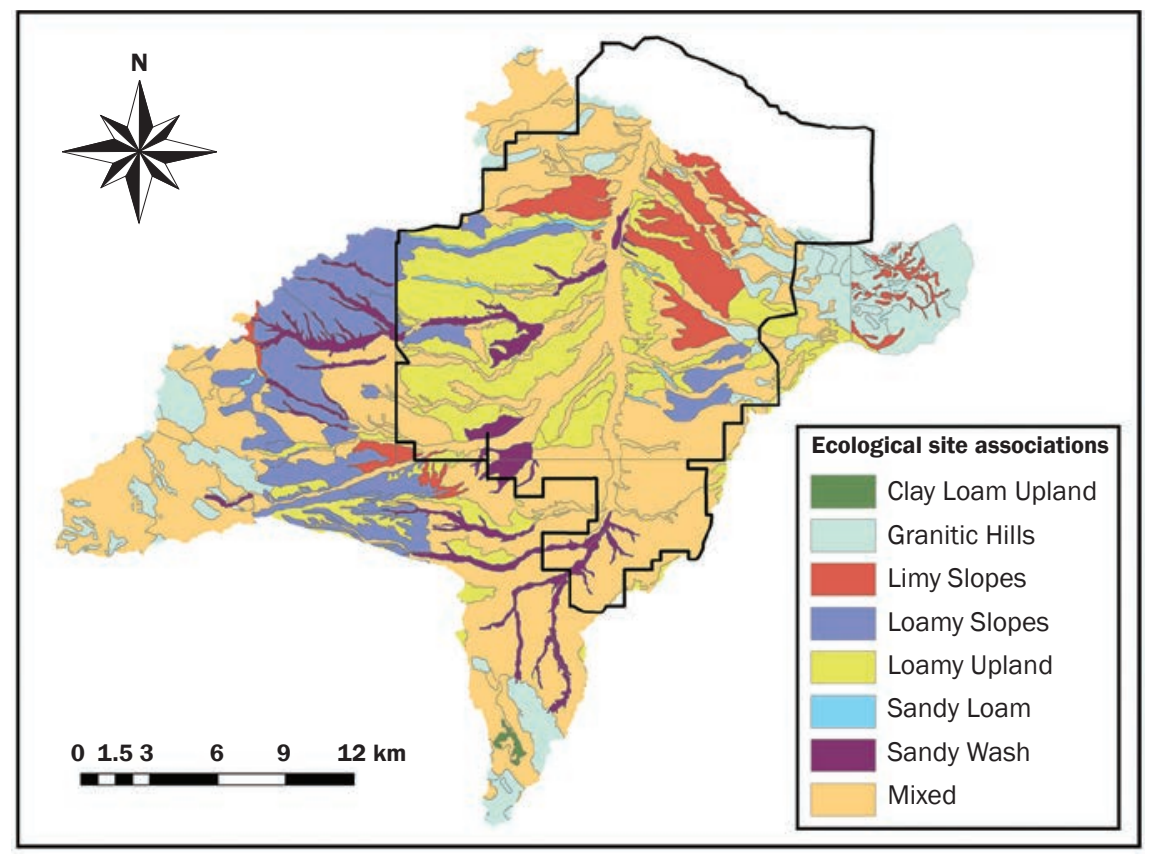

\section{Table 4}

Twenty-seven ecological sites in the Cienega Creek watershed (CCW) grouped into seven ecological site associations, plus a mixed category.

\begin{tabular}{ll}
\hline Ecological sites in CCW & Ecological site \\
\hline Clay Loam Upland 12-16" p.z.; Clay Loam Upland 16-20" p.z. & Clay Loam Upland \\
Granitic Hills 12-16" p.z.; Granitic Hills 16-20" p.z.; Limestone & Granitic Hills \\
Hills 12-16" p.z.; Limestone Hills 16-20" p.z.; Volcanic Hills & \\
12-16" p.z.; Volcanic Hills 12-16" p.z. Loamy; Volcanic Hills & \\
16-20"; Volcanic Hills 16-20" p.z. & \\
Granitic Slopes 12-16" p.z.; Limy Slopes 12-16" p.z.; Limy & Limy Slopes \\
Slopes 16-20" p.z.; Volcanic Slopes 12-16" p.z. & \\
Loamy Hills 16-20" p.z.; Loamy Slopes 12-16" p.z.; Loamy & Loamy Slopes \\
Slopes 16-20" p.z. & Loamy Upland \\
Granitic Upland 12-16" p.z.; Loamy Upland 12-16" p.z.; Loamy & \\
Upland 16-20" p.z. & Sandy Loam \\
Sandy Loam 12-16" p.z. Deep; Sandy Loam Upland 16-20" p.z. & Sandy Wash \\
Clayey Swale 12-16" p.z.; Loamy Bottom 12-16" p.z.; Loamy & \\
Bottom 12-16" p.z. (PRJU); Loamy Swale 12-16" p.z.; Sandy & \\
Wash 12-16" p.z. & \\
Areas with a combination of any two of the above ecological sites & Mixed
\end{tabular}

the ESs with environmental variable correlations (soil physical and chemical properties). PC-ORD version 7.0 (McCune and Mefford 2016) was used for multivariate analysis of the data. Results of the grouping to create the ES associations are illustrated in figure 3 and presented in table 4 . These ES associations were the spatial basis for parameterizing RHEM cover variables across the watershed.

The data sources for RHEM parameters for the large-scale assessment are summarized in table 5. In determining RHEM parameters for the ES associations, an SI greater than $50 \%$ was used to select an NRI sample to represent the RPC. This criterion has traditionally been used by NRCS to represent a good approximation of native species composition. Likewise, for the RPC, average values for RHEM foliar plant life/growth form and ground cover parameters (plant basal cover, litter, rock, and biological soil crusts) were based on NRI field sites with $>50 \%$ SI to the RPC.

The 1992 NRI data set did not record foliar and ground cover parameters; however, SI was determined based on field and ocular estimates (Spaeth et al. 2003). Therefore, to parameterize RHEM for the 1992 condition, similar to the estimation procedure for the RPC RHEM parameters, average 1992 SI values were matched with similar SI values from the 2003 to 2014 NRI data. For example, if a 1992 SI was rated fair condition (SI $=25 \%$ to $50 \%$ ), we looked at the new data for the same ES association with a $\mathrm{SI}=25 \%$ to $50 \%$ and used those NRI samples to set 1992 RHEM parameters for the corresponding ES association. Although state designations (as described in ESDs) are not recorded in the new NRI, the SI and plant community composition can provide information to match vegetative states in ES S\&TMs. For example, ES S\&TMs often list compositional changes of dominant species as well as increases or invasiveness of shrubs.

For the periods of 2003 to 2006 and 2011 to 2014 , the average NRI cover values between 2003 to 2006 and 2011 to 2014 were used, respectively, for each ES association. For areas with a combination of two ESs (the category of "mixed" in table 4 and figure 3), the average parameter values of the two corresponding ES associations were used.

Small-Scale Assessment. RHEM parameters for the small-scale assessment were aided by using Landsat images from 1992 to 2016 that were acquired over the study area to create a time series of data from which estimates for total, grass, and brush vegetative cover were derived. The imagery was also used to assess whether nationally available remote sensing products could be used to detect and track the effectiveness of rangeland conservation practices, including brush removal and fire, on canopy cover. The impact of the brush treatment was modeled using remotely sensed estimates of vegetation condition using the Rangeland Brush Estimation Toolbox (RaBET; C. Holifield Collins, personal communication, 2018; https://www. tucson.ars.ag.gov/rise/2017/Presentations/ HolifieldCollinsTalk.pdf) for 2006 and 2011, 
Table 5

Automated Geospatial Watershed Assessment (AGWA) simulations and sources of Rangeland Hydrology and Erosion Model (RHEM) parameters.

\begin{tabular}{|c|c|c|c|c|c|}
\hline Simulation & Scale & Area (ha) & $\begin{array}{l}\text { Source of RHEM parameters } \\
\text { Ground cover }\end{array}$ & Shrub foliar cover & Grass foliar cover \\
\hline \multicolumn{6}{|l|}{ Large-scale assessment } \\
\hline NRI/1992/CCW & CCW & 51,310 & $\begin{array}{l}\text { NRI } 1992 \text { and NRI } 2003 \text { to } \\
2014 \text { survey with } \\
\text { comparable SI** }\end{array}$ & $\begin{array}{l}\text { NRI } 1992 \text { and NRI } \\
2003 \text { to } 2014 \text { survey } \\
\text { with comparable SI** }\end{array}$ & $\begin{array}{l}\text { NRI } 1992 \text { and NRI } 2003 \text { to } \\
2014 \text { survey with } \\
\text { comparable SI** }\end{array}$ \\
\hline NRI/2011-2014/CCW & CCW & 51,310 & NRI 2011 to 2014 surveys & $\begin{array}{l}\text { NRI } 2011 \text { to } 2014 \\
\text { surveys }\end{array}$ & NRI 2011 to 2014 surveys \\
\hline \multicolumn{6}{|l|}{ Small-scale assessment } \\
\hline RS/2006/Small & $\begin{array}{l}\text { Small } \\
\text { watershed }\end{array}$ & 62 & $\begin{array}{l}\text { Average of NRI } 2003 \text { to } \\
2014 \text { surveys }\end{array}$ & RaBET 2006 & 2006 TFC minus 2006 RaBET \\
\hline RS/2006/CCW & $\begin{array}{l}\text { Select } \\
\text { treatment } \\
\text { areas }\end{array}$ & 6,620 & $\begin{array}{l}\text { Average of NRI } 2003 \text { to } \\
2014 \text { surveys }\end{array}$ & RaBET 2006 & 2006 TFC minus 2006 RaBET \\
\hline RS/2011/CCW & $\begin{array}{l}\text { Select } \\
\text { treatment } \\
\text { areas }\end{array}$ & 6,620 & $\begin{array}{l}\text { Average of NRI } 2003 \text { to } \\
2014 \text { surveys }\end{array}$ & RaBET 2011 & 2011 TFC minus 2011 RaBET \\
\hline RS/2016/CCW & $\begin{array}{l}\text { Select } \\
\text { treatment } \\
\text { areas }\end{array}$ & 6,620 & $\begin{array}{l}\text { Average of NRI } 2003 \text { to } \\
2014 \text { surveys }\end{array}$ & RaBET 2016 & 2016 TFC minus 2016 RaBET \\
\hline
\end{tabular}

representing pretreatment and posttreatment, respectively. Remotely sensed data provide spatially explicit information for comparison of conservation practices, and offers the potential for large area canopy cover estimates that can be obtained on a more frequent basis than NRI data. The 16-day repeat cycle and $30 \mathrm{~m}$ spatial resolution of the Landsat series of satellites (Thematic Mapper [1984 to 2011] and Operational Land Imager [2013 to present]) allowed for intra-annual, watershed-scale evaluation.

The RHEM parameters $K_{e}$ (effective saturated hydraulic conductivity), Kss (splash and sheet erodibility factor), and $f_{t}$ (hydraulic roughness coefficient) vary based on ground cover parameters (percentage basal area, percentage litter, and percentage rock) and cannot be reliably estimated from satellite-based remotely sensed data due to obstruction from the vegetative canopy. Therefore, we used the average NRI-based RHEM ground cover parameter by ES asso- ciation in the small-scale assessment. Due to these remote sensing limitations, the ground cover parameters remained static, while canopy cover inputs varied with time.

RHEM shrub cover was estimated using RaBET. RaBET is an ArcGIS-based decision support tool under development in collaboration with USDA ARS and USDA NRCS CEAP-GL to aid in assessment of their brush management conservation practice treatments. RaBET produces Landsat-based maps of woody canopy cover. These images are created within the tool using the following workflow: (1) Landsat surface reflectance images are screened for cloud cover, (2) multiple vegetation indices are calculated for each image, (3) four-year composites (i.e., the evaluation year and three preceding years) of minimum pixel values of the indices are produced to dampen the effects of high precipitation years, and (4) MLRA-specific algorithms developed between National Agriculture Imagery Program (NAIP) derived percentage woody cover (Collins et al. 2015) and Landsat-based vegetation indices were applied to the composite imagery to produce maps of percentage woody cover.

The Soil Adjusted Total Vegetation Index (SATVI; Marsett et al. 2006), developed to estimate total vegetation cover (green and senescent) in semiarid grasslands, was used to create maps of total foliar cover (TFC). A linear regression was applied using groundbased vegetation data collected on the Empire Ranch and Landsat-based SATVI:

Foliar Cover $(\%)=195.36 \times$ SATVI $+48.904 ;$ $R^{2}=0.34\left(p\right.$-value $\left.=3.1 \times 10^{-6} ; n=27\right)$.

The Empire Ranch ground data consist of line-point intercept transect measurements from $100 \mathrm{~m} \times 50 \mathrm{~m}$ sized monitoring plots collected in 2005, 2006, and 2009. These data were collected by The Nature Conservancy to track vegetation changes over time. The resulting equation was applied to the time 
series of SATVI. TFC was calculated by compositing the maximum pixel value for images obtained in August and September of a given year. Grass foliar cover images were created by subtracting the percentage woody canopy cover maps from TFC.

Conservation Practices. Using remotely sensed data with detailed spatial conservation treatment and spending information affords the opportunity to more directly evaluate the effects of conservation practices on hillslope runoff and sediment yield. The portion of the Empire Ranch was assessed where two conservation practices were implemented to remove brush: prescribed fire and mechanical treatments. Several areas with mechanical treatment also experienced wildfire in 2011 (figure 1). All the described treatments were applied between 2006 and 2011; information on additional treatments that may have been applied in these areas and within this period is incomplete and consequently not presented as part of the analysis. This section of the watershed was modeled using remotely sensed maximum TFC for the years 2006, 2011, and 2016. The year 2006 represents the rangeland condition before treatment, 2011 represents the rangeland condition just after many of the treatments were applied, and 2016 represents rangeland conditions at least six years after known treatments. The RHEM ground cover parameters were obtained from the average NRI ground cover values across all years available between 2003 through 2014 for the ES associations in the area.

\section{Results and Discussion}

Large-Scale Assessment. The effect of changing rangeland conditions in MLRA 41 was demonstrated on the CCW based on NRI data. The modeling results indicate that rangeland condition is potentially improving, although variable, given climatic conditions. As expected, erosion is relatively low for the RPC rangeland condition and higher for the preconservation (1992) period with an 11\% increase in sediment yield compared to the RPC (table 6). The preconservation time period, when the NRI data were collected, was a relatively wet period with above average annual precipitation and SPEI (figure 2).

The 2003 to 2006 period represents conditions with 7 to 11 years of EQIP spending, which was initiated in 1996 in MLRA 41. This is also during a very dry period with below average annual precipitation and SPEI (figure 2). Sediment yield was 33\% higher during the 2003 to 2006 period than for the RPC (table 6). The 2011 to 2014 period represents conditions where there has been an increase in conservation spending and implementation of conservation practices, but this period is also dry, with lower annual precipitation and SPEI values than the 2003 to 2006 period. Sediment yield was 1.7\% lower during the 2011 to 2014 period than for the RPC (table 6).

The 2003 to 2006 and 2011 to 2014 periods experienced an increase in conservation spending, although the 2011 to 2014 period represents more accumulated conservation spending, which could account for the differences in sediment yield. Another factor is seasonal variability of rainfall: the summer monsoon period between July and September receives the largest percentage of annual rainfall and is the period of the highest forage productivity. Although the annual precipitation and SPEI values are lower for the 2011 to 2014 period, rainfall for the monsoon period was consistently higher, with an average monsoon rainfall of $219 \mathrm{~mm}$ compared to $185 \mathrm{~mm}$ in the 2003 to 2006 period, showing $18 \%$ more rain on average in the later period (figure 2). Figure 4 shows that in the $\mathrm{CCW}$ TFC was higher during the 2011 to 2014 period compared to the 2003 to 2006 period, based on remotely sensed data.

Figure 5 shows the spatial variability of the relative change in sediment yield across the watershed. The 2003 to 2006 period had the highest sediment yields relative to the RPC (figure 5b). The variability in sediment yield across the watershed is due to differences in terrain and ESs. Note that increased cover conditions and reduced sediment could result from invasive species, such as Lehmann lovegrass (Eragrostis lehmanniana),

Table 6

Results for the large-scale assessment simulations for area-weighted runoff and sediment yield in hillslopes in the Cienega Creek watershed (CCW) for four simulations, and the relative changes from Reference Plant Community (RPC).

\begin{tabular}{|c|c|c|c|c|}
\hline \multirow[b]{2}{*}{ Simulation } & \multicolumn{2}{|l|}{ Runoff } & \multicolumn{2}{|c|}{ Sediment yield } \\
\hline & $\mathbf{m m}$ & $\begin{array}{l}\text { Change from } \\
\text { RPC (\%) }\end{array}$ & $\mathrm{kg} \mathrm{ha}^{-1}$ & $\begin{array}{l}\text { Change from } \\
\text { RPC (\%) }\end{array}$ \\
\hline $\mathrm{NRI/RPC/CCW}$ & 36.52 & - & $2,400.68$ & - \\
\hline $\mathrm{NRI} / 1992 / \mathrm{CCW}$ & 36.94 & 1.16 & $2,671.27$ & 11.27 \\
\hline NRI/2003-2006/CCW & 37.74 & 3.34 & $3,197.19$ & 33.18 \\
\hline NRI/2011-2014/CCW & 36.10 & -1.15 & $2,359.77$ & -1.70 \\
\hline
\end{tabular}

Note: $\mathrm{NRI}=$ National Resources Inventory. which can indicate a decrease in site condition based on the similarity index. Each ES has a unique set of parameters based on NRI points located within that ES. It should be noted that NRI points are not uniformly spread across the ESs, which creates uneven sample sizes. The low sediment yield area in the upper middle portion of figure $5 c$ (green area) is the Loamy Upland ES association, and has a low sample size $(n=1)$ for developing RPC parameters, which illustrates a disadvantage in using NRI points to capture the effects of conservation spending.

The results reinforce the importance of climate on forage production. The preconservation period, before conservation spending, has a lower average sediment yield compared to the 2003 to 2006 period with conservation spending. This is likely due to the severe drought that occurred during the 2003 to 2006 period, and the contrastingly wet climatic conditions of the preconservation period. The 2011 to 2014 period saw a substantial improvement, which may be caused by cumulative conservation spending and improved management (McClaran and Wei 2014) and higher summer rainfall. McClaran et al. (2015) noted that ranchers have become much more attuned to drought conditions since the early 2000s severe drought, resulting in a more cautious approach to stocking rates.

Process-based model predictions of sediment yield using NRI-derived RHEM parameters from MLRA 41 concluded that the trend in rangeland condition for the preconservation (1992) period was moving slightly away from the RPC. The 2003 to 2006 condition showed more departure from the RPC compared to 1992, which is likely due to the above average precipi- 


\section{Figure 4 \\ Map and graph of maximum annual foliar cover (August to September) derived from Soil Adjust- ed Total Vegetation Index (SATVI) values (1992 to 2017) for Major Land Resource Area (MLRA) 41 and the Cienega Creek watershed.}
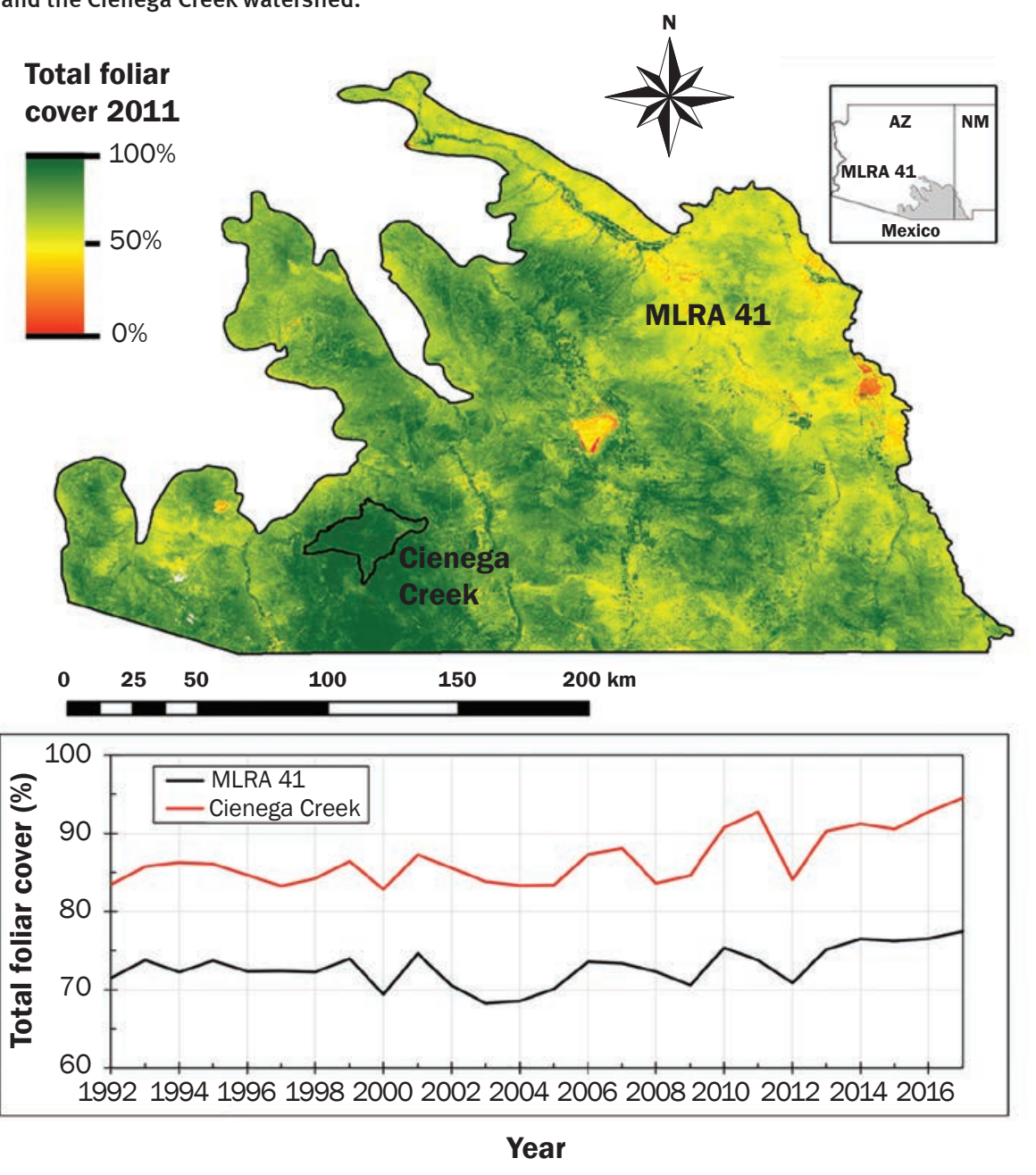

tation in 1992 and the severe drought that occurred during 2003 to 2006 . The 2011 to 2014 period showed a substantial improvement toward an average condition close to the RPC in terms of sediment yield, which is likely due to a combination of cumulative conservation investments and higher monsoon rainfall.

Average SI values have shifted from 31\% in 1992 to $30 \%$ in 2003 to 2006 , and $24 \%$ in 2011 to 2014. In addition, average shrub plant cover was stable across all periods at $\sim 13 \%$. However, nonshrub cover shifted from $32 \%$ in 1992 to $20 \%$ in 2003 to 2006 , and $44 \%$ in 2011 to 2014. Litter cover dropped from $33 \%$ in 1992 to $31 \%$ in 2003 to 2006 , and increased to $35 \%$ in 2011 to 2014 . These trends occurred from 2003 to 2014 (e.g., increasing nonshrub cover and increasing litter cover), and are consistent with findings by Bodner and Robles's study (2017) with mon- itoring data during the same time period on the Empire Ranch. Moreover, the increased nonshrub cover is possibly associated with the mortality of perennial grass and the expansion of exotic species such as Lehmann lovegrass, which led to shifts in plant composition and therefore the decline of SI.The spread of introduced species in southern Arizona is well documented (Hamerlynck et al. 2013; Van Devender et al. 1997). Fire, intensive grazing, and the warmer temperatures and prevailing drought in the early 21 st century contributed to declines in native grasses and invasion of new species in desert grasslands (Bodner and Robles 2017; Moran et al. 2014).

Small-Scale Assessment. For the select treatment areas, model results showed that the mechanical brush removal resulted in an immediate effect on simulated sediment yield (figure 6a). In 2011, most of the improvement occurred in the mechanical treatment areas. Several of the mechanical treatment areas that did not show improvement are within the perimeter of the 2011 wildfires. By 2016, all treatment areas showed decreases in sediment yield (figure 6b). The improvement occurred during a period with a warming trend, below average precipitation, and a low SPEI (lower SPEI indicates drier conditions; figure 2), suggesting the improvement in condition was primarily related to the conservation treatments. The areas in mechanical treatment experienced a reduction in the area-weighted average sediment yield of all model elements intersecting treatment polygons, from $596.8 \mathrm{~kg} \mathrm{ha}^{-1}$ in 2006 to $593.2 \mathrm{~kg}$ $\mathrm{ha}^{-1}$ in 2011 , and to $556.0 \mathrm{~kg} \mathrm{ha}^{-1}$ in 2016 , or a $6.8 \%$ reduction in sediment yield (table 7 ). The areas in prescribed fire saw an increase in sediment yield from $1,234 \mathrm{~kg} \mathrm{ha}^{-1}$ in 2006 to $1,247 \mathrm{~kg} \mathrm{ha}^{-1}$ in 2011 ; but by 2016 sediment yield was reduced to $1,190 \mathrm{~kg} \mathrm{ha}^{-1}$, or a $3.5 \%$ reduction in sediment yield (table 7 ). While these average changes are small, if we look at discrete hillslopes within the treatment areas, larger percentage reductions in sediment yield in the -6 to -19 percentage range are apparent (figure 6). The treated areas with the highest percentage reduction in sediment yield had a much greater number of trees and shrubs removed per unit area. For example, consider the following treatment areas (figure 1 and table 1): Group 1: Spring, Middle, Eagle, and Elk; Group 2: Cottonwood, Creek, and Bear; and Group 3: Rabbit, Jaguar, and Hackberry. Groups 1, 2, and $3 \mathrm{had}$ an average of 277,348 , and 124 trees $\mathrm{ha}^{-1}$ removed, respectively. The change in sediment yield for Group 3 reflects the lower intensity of mechanical brush removal. Mechanical brush removal appears to be more effective than prescribed burning in reducing simulated sediment yield, but the cost per hectare of mechanical treatment is far greater (often more than a factor of 10) based on records from the Empire Ranch (table 1).

Modeling at the small-watershed scale allowed for a more in-depth and direct analysis relating conservation spending and treatment to vegetation cover and sediment yield. The impacts of brush treatment on vegetation cover determined using RaBET were consistent with pre- and posttreatment monitoring plot data collected north of the 61.7 ha watershed in a study conducted by The Nature Conservancy to assess effective- 


\section{Figure 5}

Maps of the Cienega Creek watershed (CCW) showing relative change in sediment yield between (a) 1992 and Reference Plant Community (RPC); (b) 2003 to 2006 and RPC; and (c) 2011 to 2014 and RPC. Brown areas indicate positive change and an increase in sediment yield, green areas indicate negative change and decrease in sediment yield, white areas represent changes between $-5 \%$ to $5 \%$ that indicate no or little change in condition. The black outline is the Empire Ranch.
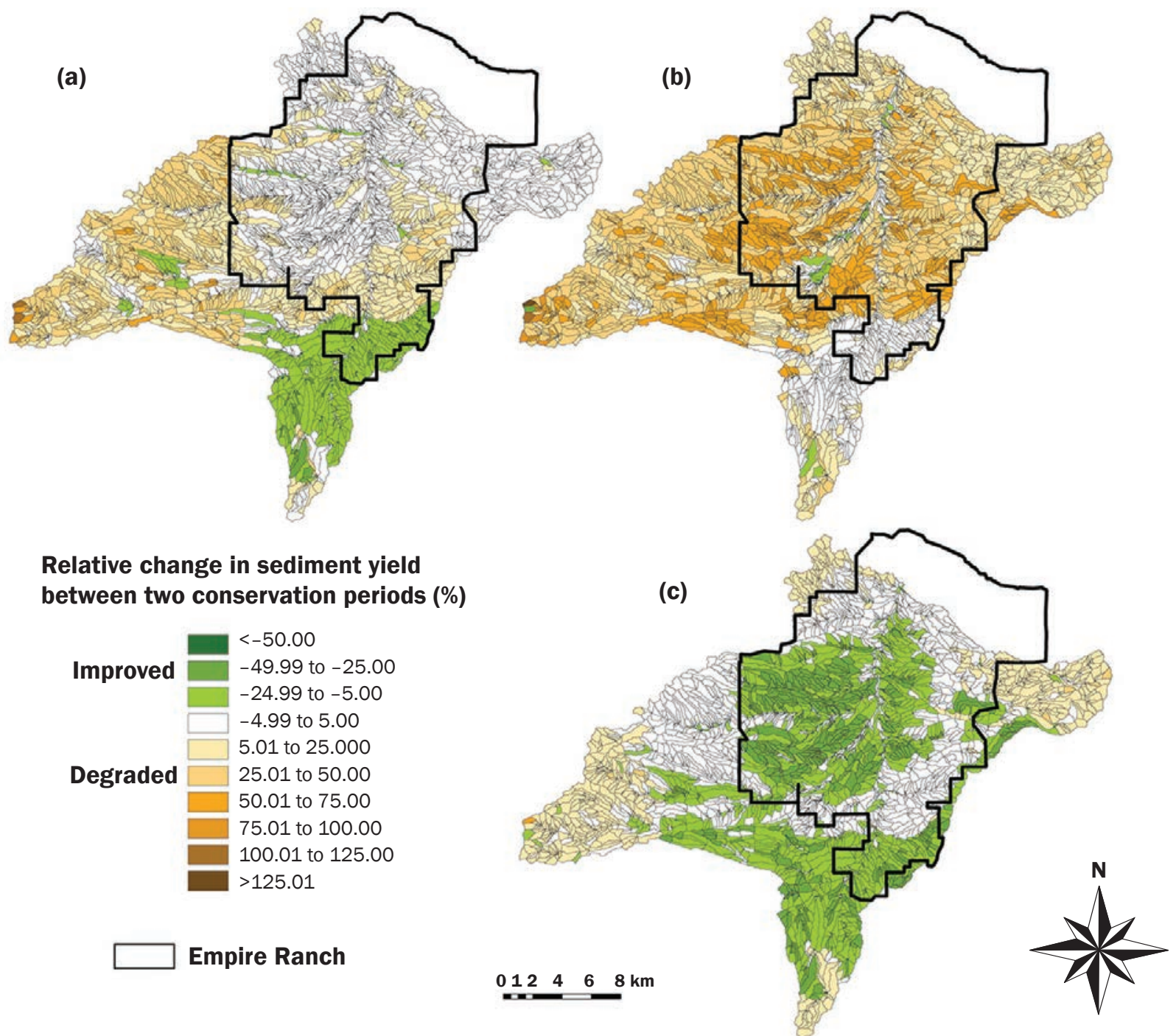

ness of brush treatments on the Las Cienegas National Conservation Area (Tiller et al. 2012). Using remote sensing to describe annual vegetation condition, along with spending and treatment data, supported modeling of pretreatment and posttreatment conditions for the select treatment areas of the CCW, including the 61.7 ha watershed that received a brush removal treatment in the winter of 2010 to early 2011 (table 1). Using the average NRI ground cover in simulations with remotely sensed data adds uncertainty to the assessment because it assumes a constant ground cover condition and reduces the simulated impact of treat- ment as it limits the model's ability to reflect the sensitivity of runoff and sediment to the change in litter and basal cover resulting from treatment.

Impact of Stock Ponds. The effect of stock ponds was also assessed since they are highly prevalent in the CCW and provide a large amount of sediment storage. Figure 7 shows the sediment yield results for the 61.7 ha watershed pre- and postbrush removal treatment, and with and without a stock pond. The percentage difference in sediment yield between pretreatment and posttreatment was $-6.4 \%$ without the stock pond and $-6.7 \%$ with the stock pond. The percentage differ- ence in sediment yield between without the stock pond and with stock pond was $-65.5 \%$ pretreatment and $-65.6 \%$ posttreatment. The results illustrate that even if conservation practices such as brush removal result in small changes in sediment yield per unit area ( $6 \%$ in this case), the accumulative effect can be large if the practice is widely applied across the landscape, but structures that capture and store sediment can also have a significant impact on downstream water quality. The much larger reductions in sediment yield due to the stock pond capturing sediment is important, as stock ponds are ubiquitous in Arizona with an estimated 


\section{Figure 6}

Maps showing results for the small-scale assessment simulations within the known treatment locations showing percentage change in sediment yield between 2006 (preconservation spending), 2011 (postconservation spending), and 2016 (later postconservation spending). Brown areas indicate positive change and an increase in sediment yield, green areas indicate negative change and decrease in sediment yield. See figure 1 for location of these areas within the Cienega Creek watershed (CCW).

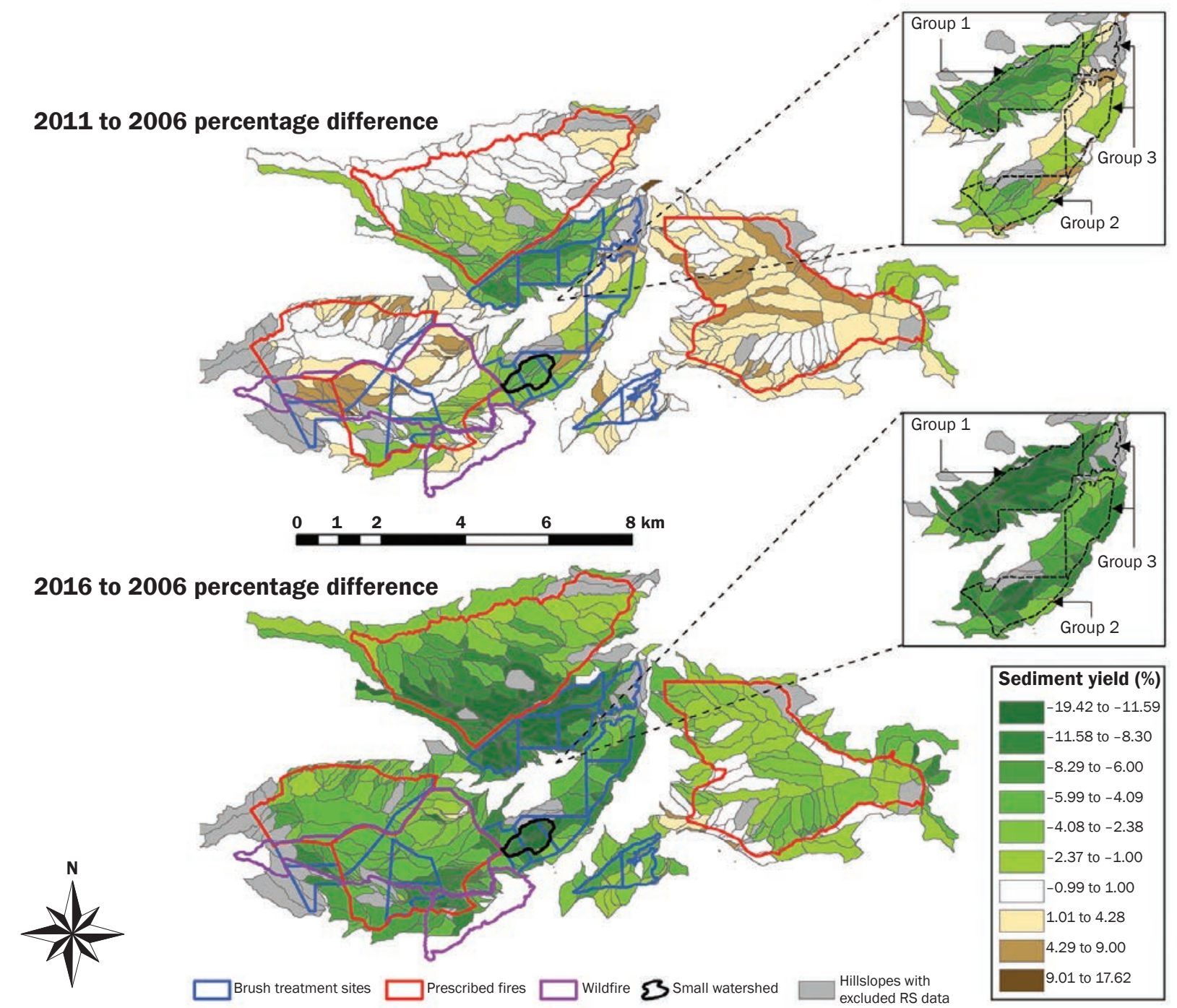

25,000 stock ponds in the $150,000 \mathrm{~km}^{2}$ Gila River Basin, including 129 stock ponds present in the CCW alone, which is a tributary to the Gila River Basin. NRCS treats stock ponds primarily as a water supply for cattle and wildlife and they are not often implemented for water quality purposes, although they directly reduce surface runoff and sediment (Berg et al. 2016; Nichols 2006). However, stock ponds must be properly maintained or sediment accumulation behind earthen dams can become an unmanaged source of sediment loading that directly impacts downstream water quality if the dam fails. While a maintained stock pond serves as an effective trap to reduce downstream sediment transport, it does not address the underlying source of erosion on hillslopes due to cover conditions that the brush treatment does address.

\section{Summary and Conclusions}

An evaluation of conservation practices implemented under CEAP-GL was conducted on the CCW in southeastern Arizona at two spatial scales using the RHEM model parameterized with NRI and remotely sensed data. The first analysis included the entire CCW and utilized NRI data from sample locations in the larger, surrounding MLRA 41. Model simulations over the CCW were conducted with RHEM parameters representing the RPC, and were compared to three periods with contrasting climate conditions and varying levels of accumulated conservation spending. The large-scale assessment results indicate that rangeland condition is potentially improving, although variable, given climatic conditions. This reinforces the importance of climate on forage production and the difficulty of separating management and climate effects (Angell and McClaran 2001; Bodner and Robles 2017; Mashiri et al. 2008; McClaran and Wei 2014), especially in the semiarid southwestern United States.

Accumulated conservation management and spending may also be a contributing factor 
for the improvement in rangeland condition but cannot be directly assessed using the NRI data. NRI sampling was designed to provide assessments over regional scales, thus firm conclusions regarding specific impacts of conservation practices are difficult (Bestelmeyer et al. 2011). However, widespread grazing management improvements, such as stocking rates, prescribed grazing practices, or drought preparation (McClaran et al. 2015) may be detected with the NRI data.

The second analysis was a small-scale assessment within the CCW that used Landsat remotely sensed data to estimate plant type (grass or shrub) and its canopy cover. Using remotely sensed canopy parameters and life form (brush or grass) derived from Landsat satellite imagery afforded the opportunity to acquire spatially explicit and more temporally dense estimates of changes in total and brush canopy cover from conservation treatments. RHEM ground cover parameters cannot be reliably estimated by the remote sensing methods used, so an average of all the NRI ground cover data used in the above analysis was employed for the simulations done with remotely sensed canopy cover. A 61.7 ha watershed within the Empire Ranch that underwent mechanical brush removal was selected for analysis. The resulting changes in brush cover were successfully detected via remotely sensed data, and pre- and posttreatment watershed simulations showed a decrease in sediment yield, indicating improved watershed conditions.

Simulation modeling using remotely sensed parameters was then performed on a larger area within the Empire Ranch containing the 61.7 ha watershed and representing select treatment areas with concentrated brush treatments where remote sensing parameters had been validated against ground data (figure 6). The simulations indicated that the mechanical brush treatment resulted in a rapid improvement in watershed conditions in the first growing season posttreatment (six to nine months after treatment). The effects of these treatments persisted or improved for over five years posttreatment. Mechanical brush treatments were typically more effective than prescribed burns for improving watershed condition as estimated by reductions in sediment yield, but were also much more costly to implement. The assessment also demonstrated the utility of using RaBET for remotely sensed estimates of woody plant cover as a model

\section{Table 7}

Results for the small-scale assessment simulations within the known treatment locations showing average percentage change in sediment yield over the specified area between 2006 (preconservation spending), 2011 (postconservation spending), and 2016 (later postconservation spending). See figure 6 for hillslope based results.

\begin{tabular}{llll}
\hline \multirow{2}{*}{ Area } & Year & \multicolumn{2}{c}{ Sediment yield } \\
\hline Bg ha & Change from 2006 (\%) \\
Brush treatment, prescribed & 2006 & $1,082.1$ & - \\
fire, and wildfire & 2011 & $1,090.7$ & 0.79 \\
Brush treatment only & 2016 & $1,039.3$ & -3.95 \\
& 2006 & 596.8 & - \\
Prescribed fire & 2011 & 593.2 & -0.61 \\
& 2016 & 556 & -6.84 \\
Wildfire & 2006 & 1,234 & - \\
& 2011 & 1,247 & 1.03 \\
& 2016 & 1,190 & -3.54 \\
& 2006 & 596.1 & - \\
& 2011 & 601 & 0.81 \\
& 2016 & 563.2 & -5.53
\end{tabular}

input to estimate changes in runoff and sediment yield with changing cover conditions over large areas.

Remotely sensed cover characteristics combined with NRI ground cover data and process models is a cost effective method to conduct large area assessments with greater temporal and spatial resolution. By conducting the assessments simultaneously over thousands of hillslopes, we are able to partially achieve the goals fostered

\section{Figure 7}

Graph showing sediment yield pre- and posttreatment for mechanical brush removal, and with and without a stock pond for the 61.7 ha watershed.

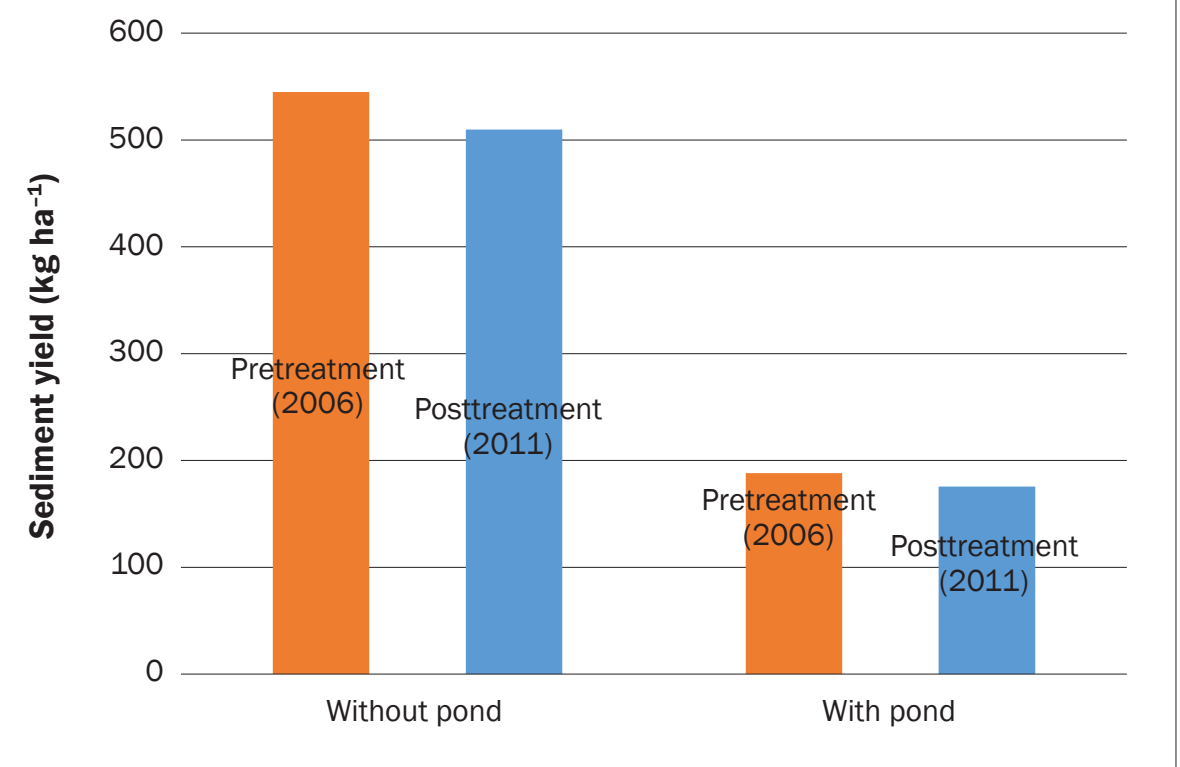

by Bestelmeyer et al. (2011) who argue for a landscape approach to assessing landscape conservation practices. The results showed that brush removal improved range condition and decreased sediment yield in the treatment areas, and that the improvements persisted for at least five years after treatment. The relative change approach used in this assessment, where we compared pre- and posttreatment, can provide valuable information to decision makers. We are able to 
observe patterns and trends at the hillslope and small watershed scale, which could be used by conservation planners to prioritize areas of high erosion risk for field inspection and focused placement of future conservation practices.

The change in simulated sediment yield from the mechanical treatment was compared to the simulations with and without a stock pond at the watershed outlet. The effect of the stock pond was roughly 2.9 times greater than the effect of brush removal. The potential importance of small ponds on regulating water and sediment yield from a watershed has been identified in other studies (Berg et al. 2016; Downing 2010; Renick et al. 2005; Verstraeten and Poesen 2001).Verstraeten and Posen (2001) reported that on an annual basis ponds can trap nearly $100 \%$ of sediments that could have been transported downstream. Nichols (2006) estimated the sediment trap efficiencies for small stock ponds in Walnut Gulch Experimental Watershed in southeastern Arizona to range from $76 \%$ to $94 \%$. Berg et al. (2016) reported that as pond numbers increased in several watersheds in Texas, sedimentation was decreased by $55 \%$. The results show that preexisting stock ponds should be included when evaluating conservation practices.

The ideal vegetation data for assessing conservation effects in a grazed watershed consists of vegetation sampled on-site at a spatial density and temporal frequency that tracks the change in vegetation and ground cover conditions due to climate, grazing activities, and conservation practices. However, such long-term data rarely exist for a watershed like Cienega Creek (or over any large area with multiple landowners) where conservation through various programs has been implemented for two decades.

Unless the lack of field data in many western rangelands is addressed, the use of remote sensing will be necessary in order to conduct rangeland assessments. This study found that remote sensing could be used to detect the effects of management and to parameterize hydrology and erosion models. To more fully use remote sensing for rangeland assessments, two possible areas of future research are suggested: (1) as the number of rangeland NRI samples grows there may be sufficient data within ESs to develop robust regressions between canopy cover and RHEM ground cover parameters, and (2) an effort to reformulate the RHEM equations might be undertaken to more fully utilize variables that could be acquired using remotely sensed data. Importantly, future rangeland conservation assessments must include the impact of stock ponds on water and sediment yield since they can have a greater impact on downstream sedimentation than vegetation manipulation, especially given the influence of climate on vegetation condition in the semiarid western United States.

This case study was conducted in the CCW in southeastern Arizona to evaluate conservation practices implemented under CEAP-GL, using different data sources describing vegetation condition. The following is a summary of the results:

1. In the southwestern United States, rangeland condition is highly influenced by the climate signal, and separating management effects from climatic effects is difficult.

2. Accumulated conservation management and spending may also be a contributing factor for the improvement in rangeland condition but cannot be directly assessed using NRI data.

3. Readily available Landsat imagery with local calibration can be confidently used to identify spatially explicit and more temporally dense estimates of changes in total and brush canopy cover from conservation treatments.

4. Watershed simulation modeling (KINEROS2 and RHEM) parameters derived from remote sensing data using RaBET can be used to assess watershed condition and brush treatment effectiveness by predicting trends in erosion and sediment yield simultaneously over thousands of hillslopes within a watershed.

5. Brush removal improved range condition and decreased sediment yield, and the improvements persisted for at least five years.

6. Stock ponds, if maintained, are nearly three times as effective in reducing sediment yield than brush removal.

\section{Acknowledgements}

Carl Unkrich (hydrologist, USDA Agricultural Research Service [ARS], Tucson, Arizona) and Gerardo Armendariz (information technology specialist, USDA ARS, Tucson, Arizona) assisted in data preparation and preparation of material for several figures. Steve Barker (principal, Resource Management System, LLC, Phoenix, Arizona) and Dan
Robinett (manager, Robinett Rangeland Resources LLC, Elgin, Arizona) provided valuable insights into rangeland conservation practices. Dan Quintana (project manager, City of Tucson, Department of Water, Tucson, Arizona) and Gita Bodner (conservation ecologist at The Nature Conservancy, Tucson, Arizona) provided treatment and monitoring data. Trent Teegerstrom (associate director, Programs Specialist, Agricultural-Resource Economics, University of Arizona, Arizona) provided the Arizona cattle population figures. We gratefully acknowledge assistance from these individuals. Support for this research and assessment was provided by the USDA Rangeland Research Program, the USDA Natural Resources Conservation Service Conservation Effects Assessment Project Watershed Assessment Studies (www. nrcs.usda.gov/TECHNICAL/NRI/ceap), and Agricultural Research Service National Program 211. This research was also a contribution from the Long-Term Agroecosystem Research (LTAR) network.

\section{Disclaimer}

The findings and conclusions in this publication are those of the author(s) and should not be construed to represent any official USDA determination or policy. USDA is an equal opportunity provider and employer.

\section{References}

Al-Hamdan, O.Z., F.B. Pierson, M.A. Nearing, C.J.Williams, M. Hernandez, J. Boll, S.K. Nouwakpo, M.A. Weltz, and K. Spaeth. 2017. Developing a parameterization approach for soil erodibility for the Rangeland Hydrology and Erosion Model (RHEM). Transactions of the ASABE 60(1):85-94

Angell, D.L., and M.P. McClaran. 2001. Long-term influences of livestock management and a non-native grass on grass dynamics in the Desert Grassland. Journal of Arid Environments 49(3):507-520.

Arnold, J.G., R. Srinivasan, R.S. Muttiah, and J.R. Williams. 1998. Large area hydrologic modeling and assessment part I: Model development 1. JAWRA Journal of the American Water Resources Association 34(1):73-89.

Berg, M.D., S.C. Papescu, B.P. Wilcox, J.P. Angerer, E.C. Rhodes, J. McAlister, and W.E. Fox. 2016. Small farm ponds: Overlooked features with important impacts on watershed sediment transport. Journal of the American Water Resources Association 52(1):67-76.

Bestelmeyer, B.T., J.R. Brown, S.D. Fuhlendorf, G.A. Fults, and X.B. Wu. 2011. Chapter 8: A landscape approach to rangeland conservation practices. In Conservation Benefits of Rangeland Practices: Assessment, Recommendations and Knowledge Gaps, ed. D.D. Briske, 337-370. Washington, DC: USDA Natural Resources Conservation Service.

Bodner, G.S., and M.D. Robles. 2017. Enduring a decade of drought: Patterns and drivers of vegetation change in a semi-arid grassland. Journal of Arid Environments 136:1-14. 
Collins, C.D.H., M.A. Kautz, R. Tiller, S. Lohani-Joshi, G.E. Ponce-Campos, J.D. Hottenstein, and L.J. Metz. 2015. Development of an integrated multiplatform approach for assessing brush management conservation efforts in semiarid rangelands. Journal of Applied Remote Sensing 9(1):096057.

Downing, J.A. 2010. Emerging global role of small lakes and ponds: Little things mean a lot. Limnetica 29(1):9-24.

Goodrich, D.C., I.S. Burns, C.L. Unkrich, D.J. Semmens, D.P. Guertin, M. Hernandez, S. Yatheendradas, J.R. Kennedy, and L.R. Levick. 2012. KINEROS2/AGWA: Model use, calibration, and validation. Transactions of the ASABE 55(4):1561-1574.

Gori, D., and H. Schussman. 2005. State of the Las Cienegas National Conservation Area. Part I. Condition and Trend of the Desert Grassland and Watershed. Prepared by The Nature Conservancy of Arizona. Phoenix, AZ: The Nature Conservancy.

Hamerlynck, E.P., R.L. Scott, and G.A. Barron-Gafford. 2013. Consequences of cool season drought-induced plant mortality to Chihuahuan Desert grassland ecosystem and soil respiration dynamics. Ecosystems 16:1178-1191.

Harmel, R.D., P.K. Smith, K.W. Migliaccio, I. Chaubey, K.R. Douglas-Mankin, B. Benham, S. Shukla, R. Muñoz-Carpena, and B.J. Robson. 2014. Evaluating, interpreting, and communicating performance of hydrologic/water quality models considering intended use: A review and recommendations. Environmental Modelling and Software 57:40-51.

Hernandez, M., M.A. Nearing, O.Z.Al-Hamdan, F.B. Pierson, G. Armendariz, M.A. Weltz, K.E. Spaeth, C.J. Williams, S.K. Nouwakpo, D.C. Goodrich, and C.L. Unkrich. 2017. The rangeland hydrology and erosion model: A dynamic approach for predicting soil loss on rangelands. Water Resources Research 53(11):9368-9391.

Herrick, J.E., J.R. Brown, A.J. Tugel, P.L. Shaver, and K.M. Havstad. 2002. Application of soil quality to monitoring and management: Paradigms from rangeland ecology. Agronomy Journal 94:3-11.

Herrick, J.E., V.C. Lessard, K.E. Spaeth, P.L. Shaver, R.S. Dayton, D.A. Pyke, L. Jolley, and J.J. Goebel. 2010. National ecosystem assessments supported by scientific and local knowledge. Frontiers in Ecology and the Environment 8(8):403-408.

Marsett, R.C., J. Qi, P. Heilman, S.H. Biedenbender, M.C. Watson, S. Amer, M. Weltz, D.C. Goodrich, and R. Marsett. 2006. Remote sensing for grassland management in the arid southwest. Rangeland Ecology and Management 59(5):530-540.

Mashiri, F.E., M.P. McClaran, and J.S. Fehmi. 2008. Longterm vegetation change related to grazing systems, precipitation and mesquite cover. Rangeland Ecology and Management 61:368-379.

McClaran, M.P., G.J. Butler, H. Wei, and G.D. Ruyle. 2015. Increased preparation for drought among livestock producers reliant on rain-fed forage. Natural Hazards 79:151-170.
McClaran, M.P., and H. Wei. 2014. Recent drought phase in a 73-year record at two spatial scales: Implications for livestock production on rangelands in the Southwestern United States. Agricultural and Forest Meteorology 197:40-51.

McCune, B., and J.B. Grace. 2002. Analysis of Ecological Communities. Gleneden Beach, OR: MjM Software.

McCune, B., and M.J. Mefford. 2016. PC-ORD for windows: Multivariate analysis of ecological data, version 7.0. Gleneden Beach, OR: MjM Software.

Miller, S.N., D.J. Semmens, D.C. Goodrich, M. Hernandez, R.C. Miller, W.G. Kepner, and D.P. Guertin. 2007. The automated geospatial watershed assessment tool. Environmental Modelling and Software 22(3):365-377.

Moran, M.S., G.E. Ponce Campos, A. Huete, M.P. McClaran, Y. Zhang, E.P. Hamerlynck, D.J. Augustine, S.A. Gunter, S.G. Kitchen, D.P.C. Peters, P.J. Starks, and M. Hernandez. 2014. Functional response of U.S. grasslands to the early 21st-century drought. Ecology 95(8):21212133, doi:10.1890/13-1687.1.

Mueller-Dombois, D., and H. Ellenberg. 1974. Aims and Methods of Vegetation Ecology. New York: John Wiley and Sons.

Nichols, M.H. 2006. Measured sediment yield rates from semiarid rangeland watersheds. Rangeland Ecology and Management 59(1):55-62.

Pellant, M., P. Shaver, D.A. Pyke, and J.E. Herrick. 2018. Interpreting indicators of rangeland health, version 5 . Denver, CO: US Department of Interior Bureau of Land Management, National Science and Technology Center.

Renwick, W.H., S.V. Smith, J.D. Bartley, and R.W. Buddemeier. 2005. The role of impoundments in the sediment budget of the conterminous United States. Geomorphology 71(1):99-111.

Sidman, G., D.P. Guertin, D.C. Goodrich, C.L. Unkrich, and I.S. Burns. 2016. Risk assessment of post-wildfire hydrological response in semiarid basins: The effects of varying rainfall representations in the KINEROS2/ AGWA model. International Journal of Wildland Fire 25(3):268-278.

Spaeth, K.E., G.L. Peacock, J. Herrick, E.P. Shaver, and R. Dayton. 2005. Current and future applications of the USDA-NRCS rangeland NRI. Journal of Soil and Water Conservation 60(5):114A-119A.

Spaeth, K.E., F.B. Pierson, J.E. Herrick, P.L. Shaver, D.A. Pyke, M. Pellant, D. Thompson, and B. Dayton. 2003. New proposed national resources inventory protocols on nonfederal rangelands. Journal of Soil and Water Conservation 58(1):18A-21A.

Spaeth, K., M. Weltz, D.D. Briske, L.W. Jolley, L.J Metz, and C. Rossi. 2013. Rangeland CEAP. Rangelands 35(1):2010, https://doi.org/10.2111/ RANGELANDS-D-12-00040.1.

Tiller, R., D. Quintana, G. Bodner, and K. Simms. 2012. Semi-desert grassland restoration in the Sky Island Region: Effectiveness of brush treatments and grassland response. Final report prepared for the National Fish and Wildlife Foundation. Tucson, AZ.

USDA NRCS (Natural Resources Conservation Service). 2018a. National Resource Inventory Rangeland Field Study Handbook. Washington, DC: USDA Natural Resources Conservation Service.

USDA NRCS. 2018b. 2018 National Resources Inventory Rangeland Resource Assessment. Washington, DC: USDA Natural Resources Conservation Service. https:// www.nrcs.usda.gov/wps/portal/nrcs/detail/national/ technical/nra/nri/results/?cid=nrcseprd1343025.

Van Devender, T.R., R.S. Felger, and M.A. Burquez. 1997. Exotic plants in the Sonoran Desert Region, Arizona and Sonora: California Exotic Pest Plant Council, 1997 Symposium Proceedings, 6 pp.

Verstraeten, G., and J. Poesen. 2001. Modelling the long-term sediment trap efficiency of small ponds. Hydrological Processes 15(14):2797-2819.

Vicente-Serrano, S.M., S. Beguería, and J.I. LópezMoreno. 2010. A multiscalar drought index sensitive to global warming: The standardized precipitation evapotranspiration index. Journal of Climate 23:1696-1718.

Williams, C.J., F.B. Pierson, K.E. Spaeth, J.R. Brown, O.Z. Al-Hamdan, M.A. Weltz, M.A. Nearing, J.E. Herrick, J. Boll, P.R. Robichaud, D.C. Goodrich, P. Heilman, D.P. Guertin, M. Hernandez, H. Wei, V.O. Polyakov, G. Armendariz, S.K. Nouwakpo, S.P. Hardegree, P.E. Clark, E.K. Strand, J.D. Bates, L.J. Metz, and M.H. Nichols. 2016. Application of ecological site information to transformative changes on Great Basin Sagebrush Rangelands. Rangelands 38(6):379-388. 